range. Dr Gösta Lagermalm, STU's senior policy adviser, agrees that because of this change of emphasis, the complaints of physicists, chemists and biologists trying to pursue "small" basic technical research are justified.

Part of the work of a governmental commission set up in 1972 to survey Swedish research councils and make suggestions for changes in their organisation was to consider this particular problem. During the commission's investigations, STU was asked to indicate those projects supported by its 1971-72 budget which had had their support reduced or cut off entirely in succeeding budgets because they were too much oriented towards basic technical research. STU replied that in 1971-72, it had given about $\$ 1.2$ million to 49 such projects. This fell in 1972-73 to just over $\$ 650,000$ for 31 projects, only four of which would be kept on for 1973-74 -all for the last time.

But approaching the problem through statistics does not really give the feel of it. Neither can it be gauged by comparing the number of applications for basic technical research grants received with those approved. As one professor at the Institute of Technology explained, colleagues of his who have been refused grants no longer apply for them, even though they still want to pursue their work and believe that it is more important for the country's technical development than the short term projects they are forced to switch to. Another said that some colleagues he knew had tried to get funds by dressing their basic technical research applications to make them look like projects which would yield practicable results quickly.

Various propositions have been put forward to find a new home for basic technical research. Some have suggested that the Natural Science Research Council should take on the job, others that STU should be given more funds in order to bring the research under its umbrella. Another suggestion was that this sort of research should have its own dispensing body. The governmental commission recommended last year that STU assume full responsibility for "support for technical research of a basic nature". This would mean setting up another grant-giving body within the framework of STU, a task which seems hardly likely to be undertaken in view of the fact that yet another commission is presently studying the aims and structure of STU itself, and is not due to report for another 18 months or so.

Thus, while the planners plan, part of the activity they are meant to be stimulating is simply being strangled, with the limiting of scientific enquiry and the lowering of morale of those academics concerned as the result.

CANADA

\title{
Council rift over report
}

The Science Council of Canada received a little more public attention over a recent incident than it wanted. David Spurgeon reports from Ottawa

THE well-known French-Canadian science broadcaster Fernand Seguin resigned from the Science Council recently when it would not publish his dissenting views on a council report on population, technology and resources. The report calls for a sharp reduction in immigration to slow Canada's population growth and maintain its high standard of living. It also proposes that Canada should use high technology to increase its food production and exports of food and raw materials.

$\mathrm{Mr}$ Seguin contended that the large increases in food exports proposed would help create a small club of privileged countries and would support the US stategy which seeks to use food as a political weapon in a way that the OPEC countries have used their oil. $\mathrm{He}$ maintained that the high technology called for in the report would require massive participation by multinational companies, a large-scale influx of foreign capital, and construction of more than 100 nuclear power plants in Canada. The upshot would be that Canada would align itself with US "food imperialism", and "hungerstricken countries would have to come and eat from our hand".

Another council member, Dr Ursula Franklin, professor of metallurgy and materials science at the University of Toronto, also disagreed with the council report. She re-assessed her position on the council as a result of the refusal to issue a minority report, but later decided not to resign, saying she would continue her participation in the council's project on the Conserver Society, of which she is head. (The Conserver Society is one of the three themes around which the council has recently structured its programme. The other two themes are technological independence and industrial strategy, and the health of the Canadian scientific community.)

In a newspaper interview ahead of the council study's publication, the study's chairman (and a former council chairman), Dr Omond Solandt, proposed cutting immigration to Canada from last year's 143,000 to an annual net figure of 50,0000 to produce a population of 28 to 30 million by the end of the century (present population is about 22 million). He argued that Canada can only export food if it does not import people. Furthermore, he said that Canada could feed four or five times as many people by exporting grain as it could if they lived in this country, since people in developing nations consume only about 400 pounds of grain a year compared to 2,000 pounds consumed by North Americans.

Energy would also be a problem, said Dr Solandt, because Canadians consume more energy than do people in developing nations. "If we brought in another 20 million, it would completely disrupt the economy," he said. "We probably wouldn't be able to feed the people brought in, and we certainly wouldn't be able to keep them warm." Dr Franklin has contended that it is not possible for a country with Canada's small population to increase food and raw material production greatly without high technology, and says this will mean that Canada will increasingly have to sell out to foreign capital. It would also require highly centralised planning.

In Dr Franklin's mind, the problem with the Science Council report is not so much with its population targets as with these problems of technology. Immigration levels can be adjusted up and down, but high technology is irreversible, she maintains. It also involves environmental and social costs, and she says council members have demonstrated an unwillingness to come to terms with the inevitable social problems.

The council chairman, Josef Kates, said the minority report was refused because it had nothing constructive to offer. French-Canadian reporters raised the issue at a press conference held to release the council's annual report only a day or two after the controversy surfaced and vice-chairman Claude Fortier, director of the department of physiology at Laval University, acknowledged that the council has published minority reports in the past.

The council accepts the right of members to differ with a majority report, but the council reserves the right to decide the mode of transmission of the minority report, he said. Sometimes this is simply a note, sometimes it is done in the letter of transmissal of the report to the Minister of State for Science and Technology (the method to be followed in this case). Dr Fortier said no report of council had had more discussion than this one (a remark that echoed Dr Solandt's comment that the study was the most difficult ever undertaken by the council). Both Dr Fortier and executive director J. J. Shepherd said they regretted Mr Seguin's departure. 